\title{
Phenolic Profile and Antioksidant Activity of Trigona Honey in Bone, South Sulawesi, Indonesia
}

\author{
Tri Damayanty Syamsul ${ }^{1}$, Rosdiana Natzir ${ }^{2}$, Suryani As'ad ${ }^{3}$, \\ Veni Hadju ${ }^{4}$, Hasyim kasim ${ }^{5}$, Andi Tenriola ${ }^{6}$, Wahyuni ${ }^{7}$ \\ ${ }^{1}$ Nursing Academy of Mappaoudang, Makassar, Indonesia, ${ }^{2}$ Professor Department of Biochemistry, Faculty \\ of Medicine University of Hasanuddin, Makassar, Indonesia, ${ }^{3}$ Professor Department of Nutrition, Faculty of \\ Medicine University of Hasanuddin, Makassar, Indonesia, ${ }^{4}$ Professor Department of Nutrition, Faculty of Medicine \\ University of Hasanuddin, Makassar, Indonesia, ${ }^{5}$ Doctor Department of Intern, Faculty of MedicineHospital of \\ Hasanuddin, Makassar, Indonesia, ${ }^{6}$ Instititute of health science of PanritaHusadaBulukumba, ${ }^{7}$ Hospital District \\ Soppeng, South Sulawesi Indonesia
}

\begin{abstract}
Introduction: Stingless bee honey has different characteristics from other types of bee honey in terms of colors, tastes, water content, and sugar. Trigona honey is one of the local products in South Sulawesi produced by stingless bees from Tetragonula species widely known to the public. This study determined the phenol content of trigona honey and its antioxidant activity.

Method: The compounds of trigona honey ethanol extract were identified using gas chromatography. The antioxidant activity of the extract was examined with the DPPH method.

Result Content test shows that trigona honey has bioactive compounds, flavonoids, alkaloids, and triterpenoids. DPPH show to trigona honey 104,25.

Conclusion: Trigona honey contains mild antioxidant activity and metabolite compounds such as polyphenols, flavonoids, alkaloids, and triterpenoids. The nutrient activity can reduce blood glucose and increase insulin plasma.
\end{abstract}

Keywords: Trigona honey, Nutritional, bioactive compounds, DPPH method.

\section{Introduction}

Honey is a natural compound made from nectar by bees. It has been used as a traditional natural therapy agent to increase immunity and prevent various diseases. Honey reduces GDP $(4,2 \%)$ and CRP $(3,2 \%)$ and increases the HDL cholesterol $(3,3 \%)^{[1]}$. Stingless bee honey has some different characteristics compared to bee honey in terms of colors, taste, viscosity, water content,

\footnotetext{
Correspondence Author:

Tri Damayanty Syamsul

Nursing Academy of Mappaoudang, Makassar, Indonesia tdamayanty@gmail.com
}

and sugar. In general, trigona honey has a darker color and a bit sour taste ${ }^{[2]}$.

Trigona honey can produce honey containing vitamin $\mathrm{C}$ that has functions as antibiotics, antitoxin, antioxidant, and can improve the immunity because the bee has a smaller size than ordinary bees. Trigona bees can collect nectar from the deepest part of a flower. As result, the honey they produce contains higher nutritional values $^{[3]}$.

Trigona honey in South Sulawesi was identified to have 27 volatile compounds classified into some groups including hydrocarbon (46.06\%), imines $(21.83 \%)$, ketones $(19.22 \%)$, acids $(7.06 \%)$, amines $(2.37 \%)$, phenolic $(1.53 \%)$, alcohol $(0.83 \%)$, oxime $(0.72 \%)$, and aldehydes $(0.38 \%)$, and there are compounds that have 
potential as antihyperglycemic. Trigona honey contains vitamins that function as antibiotics, antitoxins, and antioxidants and increase the immune system. It also (Teragonula Biroi) contains protein, fat, carbohydrates, sugar, energy, vitamin $\mathrm{C}$, beta carotene, calcium, magnesium, zinc, flavonoids, and polyphenols because trigona bees can collect nectars from the deepest part of flowers. It results in the high nutritional values it contains $^{[4]}$.

The administration of honey with the dose of 1,0 $\mathrm{g} / \mathrm{KgBB}$ can reduce the hyperglycemia and repair the oxidative stress of mice's kidneys with diabetes symptoms induced with STZ. Besides that, supplementation of Tualang honey shows protective effects on the pancreas due to diabetic oxidative stressinduced with STZ proven by the reduction of levels of lipid peroxidation markers, MDA. Treatment using tualang honey can also recover activities of SOD and catalase but still regulates the GPX activities ${ }^{[5]}$.

Supplementation of honey on diabetic mice can reduce the concentration of serum glucose and fructosamine and increase the glycemic control and repairs some metabolic disorders that are usually found in diabetes, including to decrease the levels of liver transaminases, triglycerides, and glycosylated hemoglobin (HbAlc), increases HDL cholesterol and improves cellular oxidative stress ${ }^{[6]}$. Antioxidant activities in Trigona honey contains some bioactive compounds including alkaloid, flavonoid, triterpenoid, and polyphenol ${ }^{[7]}$.

\section{Material and Method}

Plant Material: The main material used in this study was trigona honey (Tetragonula Biroi) obtained from a bees farm in Bontocane Subdistrict, Kahu District, Bone Regency, Sulawesi-Selatan. Other materials include methanol p.a (Merck), ethanol p.a (Merck), n-hexane p.a (Merck), ethyl acetatep.a (Merck), gallic acid p.a (Sigma-aldrich), reagent Folin-Ciocalteup.a, quercetin, Dimethyl sulfoxide (DMSO) p.a (Merck), aluminum chloride ( $\mathrm{Al} \mathrm{Cl3}$ ) (Merck), potassium acetate (CH3COOK) (Merck), ascorbic acid (Merck) and 1,1-diphenyl-2-picrylhydrazil (DPPH) (Sigma-aldrich).

Some tools which were used included (Philips HR 2115 Blender tango Plastik), vortex (Stuart SA8 Vortex Mixer, 230V, 50-60Hz, 20-2500rpm), rotary evaporator (Heidolph Instrument Laborota 4000), microplate 96well (IWAKI), spectrophotometer UV-Vis (U-2800
Hitachi), orbital shaker (Wise Shaker), analytical scales (Sartorius), and glasses ${ }^{[8,9]}$.

Preparation of extract: Making Trigona honey Ethanol Extract: Trigona honey was first washed and dried, then weighed as much as 100 grams, followed by the maceration process for 24 hours with $100 \mathrm{~mL} \mathrm{95 \%}$ ethanol. The extract obtained was then evaporated in an oven at a temperature of $45-50^{\circ} \mathrm{C}$ to have a volume of approximately $10 \mathrm{~mL}$. The extract was then cooled at room temperature, extraction is a process of separating the desired substance from a plant material.

\section{Research Method}

Multilevel Extraction: 100 gram of honey was macerated with non-polar solvent (n-hexane) $(1: 5 \mathrm{~b} / \mathrm{v})$ and mixed using an orbital shaker (150 rpm for $3 \times 24$ hours). The extract was filtered using Whatman 42 filter paper to get the filtrate and residue. Residue from the n-hexane solvent was reused for maceration using ethyl acetate semi-polar solvent with the same procedure with n-hexane solvent. Residue from ethyl acetate solvent was macerated again using polar solvent (methanol). Filtrates from three solvents were evaporated using a rotary vacuum evaporator at $40{ }^{\circ} \mathrm{C}$.

Determination of Total Phenolic Content: The total phenolic is determined using the principle of WanIbrahim et al. (2010). The honey extract is dissolved to form a concentration of $1 \mathrm{mg} / \mathrm{mL} .10 \mu \mathrm{L}$ of the solution was mixed into a 96-well microplate containing $160 \mu \mathrm{L}$ of aquadest. $10 \mu \mathrm{L}$ Folin-Ciocalteureagent $10 \%$ and 20 $\mu \mathrm{L} \mathrm{Na} 2 \mathrm{CO} 310 \%$ solution were added into each well and incubated for 30 minutes at room temperature. The total phenolic content was identified by reading the absorbance at the wavelength of $750 \mathrm{~nm}$ using a microplate reader. The total phenolic of the sample was determined using a standard curve of gallic acid with various concentrations $(20,40,60,80,100 \mu \mathrm{g} / \mathrm{mL})$ and the result was in milligram per gram gallic acid $(\mathrm{mg} / \mathrm{g}$ GAE). The total phenolic content of each extract was stated as Gallic Acid Equivalent, which was a general reference to measure the phenolic compounds in a material ${ }^{[10]}$.

Determination of total flavonoid: The determination of total flavonoid content refers to Son et al. (2015). The honey extract was dissolved using ethanol to form the concentration of $1 \mathrm{mg} / \mathrm{mL}$ and $10 \mu \mathrm{L}$ of the solution was taken and mixed into a 96-well microplate containing $120 \mu \mathrm{L}$ of aquadest. Aluminum chloride $10 \%$ 
and acetic acid solution (10 $\mu \mathrm{L}$ of each) and $60 \mu \mathrm{L}$ of ethanol were added into each well and incubated for 30 minutes in the temperature room. The total phenolic content was identified by reading the absorbance at the wavelength of $415 \mathrm{~nm}$ using a microplate reader. Quercetin was used as a standard. The total flavonoid content ofthe sample was determined based onquercetin standard curve with various concentrations $(50,100$, $150,200,250$, and $300 \mu \mathrm{g} / \mathrm{mL}$ ) and the result was in milligram per quercetin (mg/g QUE) that is the milligram of quercetin equivalent per $1 \mathrm{~g}$ extract ${ }^{[11]}$.

\section{Analysis of Antioxidant Activities Using the DPPH (2,2-diphenyl-1-picrylhydrazyl) method:} Analyzing the antioxidant activities using the DPPH method referred to Li et al. (2012). $10 \mathrm{mG}$ of the extract was dissolved with $1000 \mu \mathrm{L}$ Dimethyl sulfoxide. 200 $\mu \mathrm{L}$ extract solution was pipetted into a microplate and added with $100 \mu \mathrm{L}$ DPPH solvent with a concentration of 125 micromolar in ethanol p.a. The mixture was homogenized and incubated at a temperature of $37^{\circ} \mathrm{C}$ for 30 minutes. The positive control was ascorbic acid with a concentration of 1,25-20 ppm. Ethanol p.awas used as anegative control. The absorption was measured using a microplate reader at a wavelength of $517 \mathrm{~nm}$. Radical inhibition activities DPPH (\%) can be calculated using the following formula ${ }^{[12]}$.

\section{Results}

Table 1 Flavonoid dan polyphenol

\begin{tabular}{|l|c|}
\hline Parameters & Trigona honey \\
\hline Polyphenol & $133.52 \mathrm{ppm}$ \\
\hline Flavonoid & $159.62 \mathrm{ppm}$ \\
\hline Protein & $1.32 \%$ \\
\hline Vitamin C & $0.15 \%$ \\
\hline Carbohydrate & $64.12 \%$ \\
\hline Fat & $0,23 \%$ \\
\hline Beta carotene & $10.61 \mathrm{ppm}$ \\
\hline Magnesium & $338.94 \mathrm{ppm}$ \\
\hline Calcium & $273.23 \mathrm{ppm}$ \\
\hline pH & 5.76 \\
\hline Zinc & $12.49 \mathrm{ppm}$ \\
\hline
\end{tabular}

The table 1 show that of Trigona Honey, show that there waspolyphenol was $133.52 \mathrm{ppm}$, while the total flavonoid of trigona honey (ethanol test of 96\%) was 159.62 ppm. $0.15 \%$ vitamin C, $1.32 \%$ Protein, $0.23 \%$ Fat, $64.12 \%$ carbohydrates, $10.61 \mathrm{ppm}$ beta carotene, 273, 23 calcium, 338.94 magnesium, and $12.49 \mathrm{ppm}$ zinc and the $\mathrm{pH}$ was 5.76 .

Tabel 2. Trigona honey antioxidant activity testing

\begin{tabular}{|c|l|c|c|c|}
\hline No & Test Parameter & Result & Unit & Method \\
\hline 1. & Aktivitas Penangkapan radikal bebas DPPH $\left(\mathrm{IC}_{50}\right)$ & 104,25 & $\mathrm{mg} / \mathrm{l}(\mathrm{ppm})$ & Spektrofotometri-Uv \\
\hline
\end{tabular}

\section{Discussion}

The test results in table 2 above indicated that the lower the absorbance percentage, the higher the honey concentration $(104,25 \mathrm{mg} / \mathrm{I})$. Antioxidant activities were tested to identify the free radical scavenging activity (IC50) of trigona honey (Tetragonula biroi). The test showed a score of $104,25 \mathrm{mg} / \mathrm{I}$ (ppm).According to Molyneux, P (2204) value $\mathrm{IC}_{50} 100-150$ ppm indicates average antioxidant activities. The working principle of the DPPH test was that the bioactive compound as an antioxidant will reduce the free radicals DPPH into 1,1-diphenyl-2-picrylhydrazine. DPPH reacts with antioxidant to form reduced diphenyl picryl hydrazine and antioxidant radicals.

An antioxidant is a compound that can protect the cell from damages caused by an unstable molecule called free radicals (Sies, 1997). Antioxidant activities are presented in decoloration percentage (\%) using spectrophotometer UV-Vis. Radical compounds used in testing the antioxidant activities were 2,2-diphenyl1-picrylhydrazyl (DPPH). The maximum absorbance of DPPH compounds is at the wavelength between 515 $520 \mathrm{~nm}$ (Martysiak-Żurowska and Wenta, 2012) ${ }^{[13]}$.

In the Antioxidant activities of trigona honey (Tetragonula Biroi), there are some bioactive compounds including alkaloid, flavonoid, triterpenoid, and polyphenol. Flavonoid is a compound that is closely related to substances with antioxidant capacity for the body. The administration of antioxidants canreduce the oxidative stress level so that premature aging and complication of various diseases can be inhibited. Trigona honey has potentials as an antioxidant, antibacterial, antihyperglycemic and antidiabetic. 
Polyphenolcontains antioxidant compounds that can reduce the oxidative stress by preventing changes in the superoxide chain $\left(\mathrm{O}_{2}\right)$ into hydrogen peroxide $\left(\mathrm{H}_{2} \mathrm{O}_{2}\right)$ due to habe wells reaction dan Fentorwill form hydroxyl radical $(\mathrm{OH})$. Polyphenols donate hydrogen atoms from the aromatic hydroxyl group (-OH)to bind free radicals and get rid of them from the body through the excretion system (Eliasson,L et al 2008). Polyphenol has some benefits to prevent and cure degenerative diseases like diabetes, cancer, and blockage of blood vessels. The polyphenols in honey can scavenge hydroxyland peroxyl alcohoxyl radicals because they can act as hydrogen donors. That is why they have antioxidant properties. Besides phenolic and flavonoid compounds, honey also contains Vitamin $\mathrm{C}$ as an antioxidant compound.

Researchers found that flavonoid is a very useful antioxidant as an anti-inflammatory by interrupting the effects of the arachidonic acid metabolic pathway, influencing the production of prostaglandins and release of histamine, cutting off tumor promoter activity (antitumor activity), and interrupts nucleic acid synthesis (antivirus) $^{[14,15,16,17]}$.

An in vivo study shows that honey can stimulate antioxidant defense system in mice's pancreas, serum, kidney, and liver by stimulating the activity of cellular antioxidant enzymes such as superoxide dismutase, CAT, glutathione peroxidase, glutathione S-transferase and more significant reduction of glutathione levels ${ }^{[18]}$.

Another study showed that food rich with an antioxidant like honey can inhibit the damaging effects of free radicals and ROS like protecting the cardiovascular by preventing and reducing the induction of lipoprotein density ROS (LDL) oxidation (Schramm et al. 2003); cell death in somecell line cancers (Jaganathan et al. 2015); increase the antioxidant immunity in humans ${ }^{[19]}$.

An in vivo study using 28 Wistar mice induced with streptozotocin and randomly divided into four groups. The result showed that the administration of honey was considered as an anti-atherogenic factor. Honey can increase glucose and lipid metabolisms and lipid profiles but can reduce the oxidative stress-mediated by lipid peroxide through the reduction of the MDA level. It is because honey has anti-radical properties and antioxidant activity thus can reduce the free radicals ${ }^{[20]}$.

\section{Conclusion}

Trigona honey contains polyphenol (133,52 ppm) and flavonoid $(159,62 \mathrm{ppm})$. Antioxidant activities of trigona honey are in the medium category that is 104,25 $\mathrm{mg} / \mathrm{I}$, therefore trigona honey (TetragonulaBiroi) has a big potential as a natural antioxidant for Diabetes mellitus therapy.

Acknowledgment: The authors would like to thank my supervisor in Hasanuddin university, Mappaoudang Nursing of academy, for warm support LPDP, and the Ministry of Research Technology and Higher Education of Republic Indonesia, for providing the scholarship during this study and

\section{Conflict of Interest: Nil}

Funding Source: By self

Ethical Clearance: The ethical committee of Hasanuddin university, medicine faculty confirmed the protocol and the ethical code is as follow UH19020081.

\section{Reference}

1. Mushtaq Re, Mushtaq Ru, Tasawur ZK. Effect of natural honey on lipid profile and body weight in normal weight and obese adults : A randomized clinical trial. Pakistan J. Zool; 2011;43 (1): 161-9

2. Garedew A, Schmolz,A, Lamprecht ingolf. The antimicrobial activity of honey of the stingless bee Trigona spp. Journal of apicultural science. 2003; 47 (1): 37-49.

3. Ngoi $V$,. Effect of processing treatment on antioxidant, physicochemical and enzymatic properties of honey (Trigona spp). Univ Tunku abdul rahman, Malaysia.2016

4. Tri Damayanty Syamsul, Rosdiana Natzir, Suryani As'ad, Veni Hadju, Mochammad Hatta, Sutji Pratiwi, Andi Tenriola. The chemical composition of trigona honey. Indian journal of public health research and development. 2020;11(9): 235-241

5. Erejuwaa, O.O, SIti A Sulaiman, Mohd S Ab Wahab. K.N.S Sirajudeen, M.S.MD. Salleh,S. Gurtu. Antioxidant protection of Malaysian Tualang honey in pancreas of normal and streptozotocin induced diabetic rats. USM,Malaysia. 2010.

6. Erejuwaa,O.O. Effect of honey in diabetes mellitus: matters arising. Journal of diabetic metabolik disorders. 2014;13-23

7. Eliasson, L. Abdul Kader,F., Braun, M.G Alvanovskis, J., Hoppa M.B,. and Rorsman, P. "Novel aspects of the moleculer mechanism 
controlling insulin secretion”. J. Physiol. 2008; 586 (14) : 13-24

8. Hatta M, Surachmanto EE, Islam AA, Wahid S. Expression of mRNA IL-17F and sIL-17F in atopic asthma patients. BMC Res Notes. 2017;10(1):202

9. Jafriati J, Hatta M, Yuniar N, Junita AR, Dwiyanti R, Sabir M, Primaguna MR. Mini Review: Thalassia hemprichii Seagrass Extract as Antimicrobial and Antioxidant Potential on Human. Journal of Biological Sciences. 2019: 363-371.

10. Xuewang,et al. Relationship between total phenolic contents and biological properties of propolis from 20 different regions in south korea. BMC Complementary and alternative medicine. 2016 : $16: 65$

11. EviSulastri et al. Total phenolid, total flavonoid, Quercetin content, and antioxidant activity of standardized Extract of Moringa oleifera leaf from regions with different elevation. Pharmacogn J. 2018;10 (6) :104-108

12. Rachid skuota, et al. Assessing the antioxidant properties of Larrea tridentata extract as a potential molecular therapy against oxidative stress. Molecules. 2018; 23.1826. www.mdpi.com/ journal/molecules

13. Sagar B. Kedare, R.P. Singh. Genesis and development of DPPH method of antioxidant assay. J. Food sci Technol. 2011; 48 (4) : 412-422
14. Winarsi, H. Antioksidan Alami dan Radikal Bebas. Kanisius. Yogyakarta. 2007.

15. Robinson, T. Kandungan Organik Tumbuhan Tinggi. Edisi VI. Kosasih Padmawinata. ITB. Bandung. 1995; 191-216.

16. Andersen, O.M. and Markham, K.R. Flavonoid: Chemistry, Biochemistryand Applications. Taylor and Francis Group. United States of America.2006.

17. Mark N. feinglos, M.Angelyn Bethel,. Type 2 Diabetes Mellitus An evidence Based approach to practical management, Duke University Medical Center, Durham, NC.USA. Humana press). 2008

18. Alejandra Anahí Romero-Ortíz1, Beatriz Elina Martínez-Carrillo1, Arturo G. Rillo2, Martha Liliana Palacios-Jaimes3, Javier Jaimes-García4, Javier Jaimes-Cienfuegos. Journal of Pharmacy and Biological Sciences (IOSR-JPBS).Honey and Type 2 Diabetes Mellitus: Reconstruction of Problematic Field Using the Lakatosian Method. 2017;12:2

19. Schramm DD, Karim M, Schrader HR, Holt RR, Cardetti M, Keen CL . Honey with highlevels of antioxidants can provide protection to healthy human subjects. J Agric Food Chem. 2003;51:17321735

20. Hemmati, Mina, et al. Antiatherogenic potential of natural honey: antidiabetic and antioxidant approaches. Journal of Pharmacy and Pharmacology 3. $2015 ; 278-284$. 